J. Product. \& Dev., 25(3): 297-306(2020)

\title{
SPECIFIC CARBOHYDRATE HYDROLYZING ENZYMES IN RELATION TO DIFFERENT INSECTICIDES TREATMENTS IN WHITEFLY, Bemisia tabaci
}

\author{
Amira M. Mohamed; Mohana, A.H. ${ }^{1}$; El-Sharkawy, H.M. ${ }^{1^{*}}$ and E.H. Salem ${ }^{2}$ \\ ${ }^{1}$ Plant Production Department, Faculty of Technology and Development, \\ Zagazig University, Zagazig, Egypt . \\ 2 Plant Protection Research Institute ( Branch Zagazig); Center Agric. \\ Research, Giza, Egypt._*email: hamzash@hotmail.com
}

\section{ABSTRACT:}

Toxicity of acetamiprid (mospilan 20\% Sp), chlorpyrifosmethyl (reldan22.5\% EC) and pyriproxyfen (admiral 10\% Ew) against laboratory and field strains of whitefly, Bemisiatabaci was studied. Evaluation of biochemical alterations of carbohydrate hydrolyzing enzymes (amylase, trehalase and invertase)activity were recorded and discussed as biomarkers for acetamiprid, chlorpyrifosmethyl and pyriproxyfen toxicity in the both of strains of B.tabaci. Results indicated that these compounds decreased the activities of amylase and trehalase enzymes in laboratory and field strains. Regardingto invertase enzyme, acetamiprid increased the activity ofinvertase enzymein the two strains while chlorpyrifos-methyl elevated the activity of invertase enzyme in laboratory strain, pyriproxyfen reduced the activity of invertase enzyme in both strains. Field study was conducted to evaluate the efficacy of tested insecticides against the adults of B. tabacion tomato crop, during seasons 2018 and 19 at Zagazig district, Sharkia Governorate.

Results showed that acetamiprid was the most effective insecticide in both seasons, which achieved 86.81 and $88.20 \%$ of reduction percentage in $B$. tabaci population, followed by chlorpyrifos- methyl recording 77.17 and $81.82 \%$, pyriproxyfen was the least potent compound which recorded 59.58and $63.62 \%$ of reduction percentage in the pest population in seasons 2018 and 2019 respectively.

Conclusively, it was proved through this study that the neonicotined, acetamiprid was the most potent toxicant against $b$. tabaci, so we used acetamiprid in B. tabaci management.

Key words: Whitefly, acetamiprid, chlorpyrifosmethyl, pyriproxyfen, relative activity. 


\section{INTRODUCTION:}

The cotton whitefly, Bemisiatabaci (Genn.) (Hemiptera: Aleyrodidae) is one of the most global destructive pests (Jiao et al., 2012; Ghosal and Chatterjee, 2012). Whitefly is a sucking insect that suck the plant Juice from more than 500 host plant species (Hunter and Polston, 2001), causing indirect damage of plant leaf by expelling honeydew which is considered a base for black sooty mold fungi growth (Berlinger,1986; EFSA,2013), the molds cause the suppression of photosynthesis and reduce the market value of yield (Belinger,1986). As well as whitefly can transmit more than 100 virus species (EFSA,2013) involving the tomato yellow leaf curl virus (Ghanim and Czosnek, 2000), the sweet potato leaf curl virus (Lotrakol et al., 1998) and the tomato mottle virus (Hunter et $a l ., 1998)$. In many agricultural systems, management of whitefly largely relieson insecticides application suchas; Neonicotinoids ,organophosphorus insecticides Ops), insect growth regulators (IGRs), carbamates and pyrethroids (Sayed Abdul Rahman et al., 2000). Because of intensive applications of chemicals, B.tabaci has developed high resistance to conventional used compounds (Ahmed et al, 2010; Li et al., 2012 ).

Therefore, it is urgent to develop new or non-conventional compounds to control highly resistant $B$. tabaci and to preserve their efficacy by applying insecticides resistance management strategies (Horowitz et al., 1998).

\section{MATERIALS AND METHODS:}

\section{Tested insecticides:}

Acetamiprid (Mospilan 20\% Sp.) provided by Qingdao KYX chemicals Co.Ltd.Chlorpyrifos-methyl (Reldan $22.5 \%$ EC) provided by Syngenta Company. Pyriproxyfen (Admiral10\%EW) provided by Sumitomo Company.

\section{Tested insect:}

The whitefly adults of laboratory and field strains treated with $\mathrm{Lc}_{50}$ value of tested insecticides were determined. They were 1.79 and12.14 ppm for acetamiprid, 3.61 and 35.92ppm for chlorpyrifos- methyl, and 6.25 and $49.52 \mathrm{ppm}$ for pyriproxyfen for laboratory and field strains, respectively. 


\section{Preparation of Insects for analysis:}

After treatments, the survival adults were collected from each treatment and from control by inspirator after $24 \mathrm{~h}$ for acetamiprid and chlorpyrifos-methyl, and $72 \mathrm{~h}$ for pyriproxyfen, and transferred into $1.5 \mathrm{ml}$ micro centrifuge tubes Each tube was labled according to the tested compound and control, containing $(1 / 2) \mathrm{g}$ of adults. Samples were stored at $-20^{\circ} \mathrm{C}$ untilbio chemical analysis.

Determinationof carbohydrate hydrolyzing enzymes activity (amylase,trehalase and invertase)

Digestive enzymes were determined according to the modifications of Amin (1998) to the method described by Ishaaya and Swirski (1976).

\section{Data analysis:}

Data obtained were analyzed by probit analysis (Finney, 1971) to estimate ( $\mathrm{LC}_{50}$ and confidence limits values ).

\section{Field studies:}

The field experiment was carried out at tomato field in Zagazig district, Sharkia Governorate, during seasons 2018 and19; to evaluate the efficacy of tested insecticides against Bemisia tabaci under the field conditions.An area of about (11 kirrat) was divided into 4 equal plots (3 treatments in addition to control ). Treatments were arranged in a randomized complete block design with four replicates.

The treatments were applied when the pest crossed the economic threshold level (ETL) .Aknapsack sprayer (20 litter )was used and filled with the recommended concentrations of each insecticide.

During application of insecticides, consideration was taken to make sure that the whole entire leaves surface was sprayed since whiteflies were attacked at the under sides of leaves, the plot of control was sprayed with water. For counting the numbers of adults and immature stages, samples of 25 tomato plants were collected randomly from each replicate and placed in paper bags then brought to the laboratory for examination, they were examined one day before treatment, after 1,3,5,7 and 10 days for (Acetamiprid and chlorpyrifos-methyl), and after 3, 5, 7 and 10 days for pyriproxyfen. The reduction percentage were computed according to the equation of Hinderson and Telton (1955). 


\section{RESULTS AND DISCUSSION:}

\section{Biochemical effects of tested compounds on laboratory and field strains of whitefly, Bemisia tabaci}

a-carbohydrate hydrolyzing enzymes activities

Results in Table (1) showed the changes in the activity of carbohydrate hydrolyzing enzymes (amylase, trehalase and invertase) of the adults after treatments with different insecticides.

\section{1-Amylase}

Starting from amylase which hydrolyzing starch in the biological systems in whitefly,B.tabaci. Certain insecticides caused a variable levels of inhibition in amylase activity in the laboratory and field strains. Acetamiprid appeared a slight inhibition $(-13.07 \%)$ in the enzyme activity in the laboratory strain, while the inhibition elevated to $(-40.45 \%)$ of enzyme antagonism in the field strain compared with control for each of them.Continently the inhibition of amylase activity in the laboratory strain was $(-23.34 \%)$, which increased to(-31.02\%)of enzyme inhibition in the field strain after treated with chlorpyrifos-methyl. The decleration in the activity of amylase enzyme was observed in the field strain after treated with pyriproxyfen in a level of inhibition(-9.94\%) as compared with laboratory strain, which revealed an elevation in amylase high level in amylase inhibition(-31.24\%).

\section{2-Trehalase}

On the other hand, trehalase which hydrolyzing trehalose sugar, inhibition of trehalase activity was substantially in the field strain, recording $(-43.42 \%)$ comparison with laboratory strain which appeared $(-15.11 \%)$ of delaying in the enzyme activity after treated with acetamiprid, followed by chlorpyrifos-methyl which caused $(-32.06 \%)$ of enzyme inhibition in the field strain, and(-25.23\%)in the laboratory strain. Pyriproxyfen caused a considerable effect in the enzyme activity, recording $(-27.05 \%)$ in the laboratory strain, whereas the enzyme reached a weak level of inhibition, recording(-18.86\%)in the field strain.

\section{3-Invertase}

Regarding to the invertase enzyme, which hydrolyzing sucrose, the rate of inhibition in the invertase activity was noticeable with pyriproxyfen 


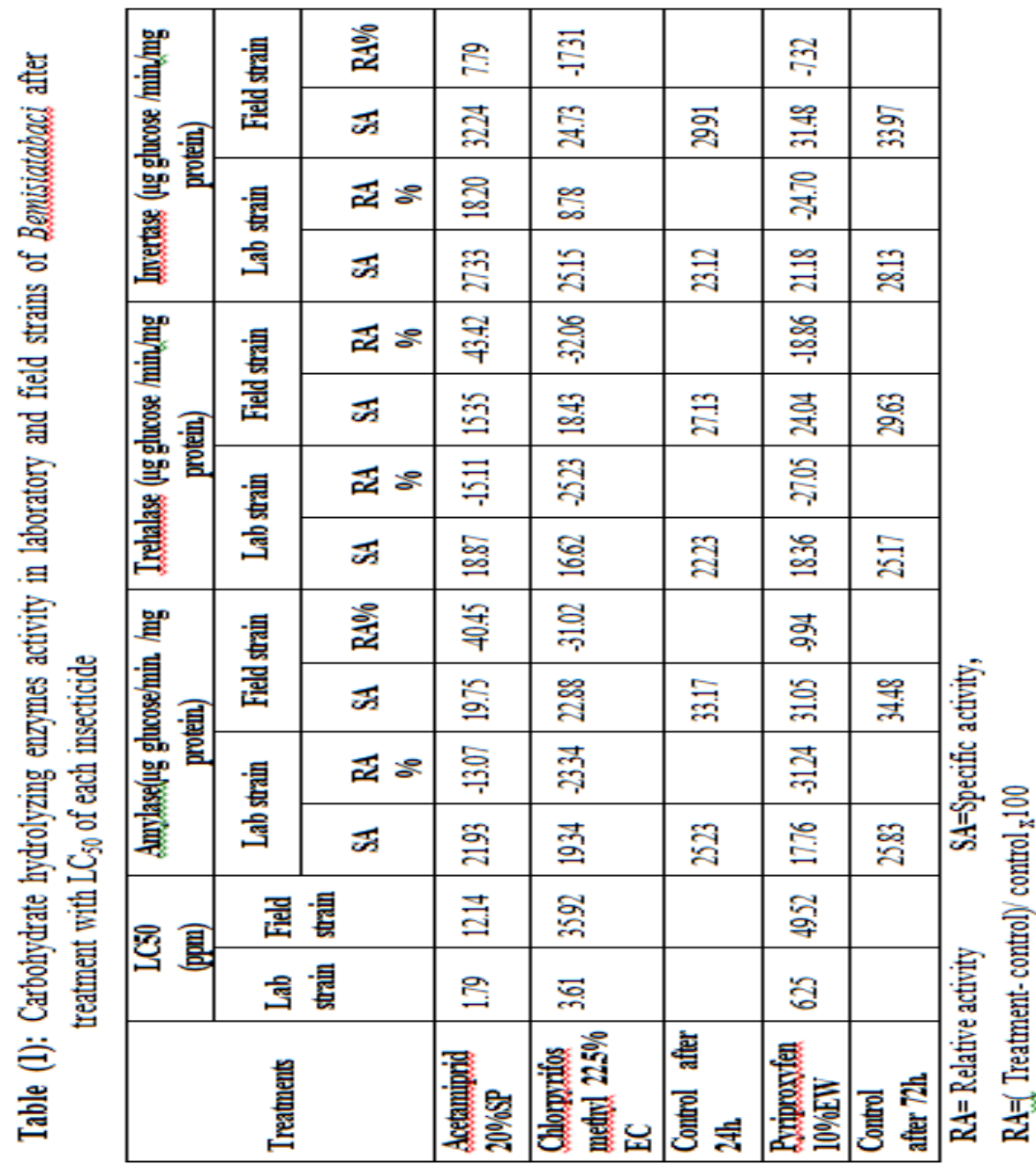


in the laboratory strain, $(-24.70 \%)$, whereas the enzyme inhibition dropped to $(-7.32 \%)$ in the field strain. Given to the inhibition in the field strain was seen after treatment with chlorpyifos-methyl, recording $(-17.31 \%)$ while the laboratory strain recorded $(8.78 \%)$ of synergism. Clear synergism without any inhibition was observed in the field strain after treated with acetamiprid, recording (7.79\%)of enzyme activity in the field strain, which elevated to $(18.20 \%)$ of synergism in laboratory strain.

The present results are supported with Azabet al.(2011) who studied biochemical effect of seven insecticides (acetamiprid, imidaclopride, chlorpyrifos, profenofos ,botany grad, orizon (acetamiprid +abamectin) and cloves oil) on the activity of carbohydrate hydrolyzing enzyme (amylase, trehalase and invertase).

Results indicated that these insecticides appeared different effects on the activity of carbohydrate hydrolyzing enzymes, acetamiprid and chlorpyifos methyl caused decrease in the activity enzymes.

\section{Field studies:}

Effect of tested insecticides against the adults of whitefly, Bemisia tabaci on tomato crop under field conditions:

Data represented in Tables $(2 \& 3)$ showed the efficacy of insecticides acetamiprid (mospilan 20\% Sp), pyriproxyfen (admiral $10 \% \mathrm{EW}$ ) and chlorpyrifosmethyl (reldan $22.5 \%$ EC) against the adults of B. tabaciat the recommended rate during the two seasons of 2018 and 2019.

Data in Table (2) showed that the reduction percentage in $B$. tabaci population was recorded till 10 days after treatments. These data indicated that all tested insecticides caused increasing in the reduction percentages during all time intervals. Effect of acetamiprid started after one day of treatment, recording (90.98\%) and continued till the end period of 10 days, giving $(77.25 \%)$ of reduction percent, effect of chlorpyrifos-methyl improved after 1day of treatment recording $(86.15 \%)$ and marched at the same trend till recorded(64.44\% )of reduction percent at the end period of 10 days. Effect of Pyriproxyfen appeared after 3 days of treatment giving $(59.53 \%)$ and $(50.28 \%)$ of reduction percent at the end period of 10 days.

On the other hand, acetamiprid introduced the highest mean of $(86.81 \%)$ followed by Chlorpyrifos-methyl at level of $(77.17 \%)$ while pyriproxyfen gave the least mean of reduction percent $(59.58 \%)$. There were significant differences between the three insecticides. 
Table (2): Reduction percentages in adults of Bemisia tabaciaftertreatments with different insecticides on tomato crop duringseason 2018

\begin{tabular}{|c|c|c|c|c|c|c|c|}
\hline \multirow{2}{*}{$\begin{array}{l}\text { Tested } \\
\text { insecticides }\end{array}$} & \multirow{2}{*}{$\begin{array}{l}\text { Recommended } \\
\text { rate }\end{array}$} & \multicolumn{5}{|c|}{ Reduction \% } & \multirow{2}{*}{$\underset{\%}{\text { Mean }}$} \\
\hline & & 1day & 3days & 5days & 7days & 10days & \\
\hline $\begin{array}{l}\text { Acetamiprid } \\
20 \% \mathrm{SP} \\
\end{array}$ & $\begin{array}{l}25 \mathrm{gm} / 100 \\
\text { liter water } \\
\end{array}$ & 90.98 & 93.06 & 89.07 & 83.70 & 77.25 & $86.81^{a}$ \\
\hline $\begin{array}{l}\text { Chlorpyrifos- } \\
\text { methyl } \\
22.5 \% \text { EC }\end{array}$ & 1liter /feddan & 86.15 & 83.49 & 79.08 & 72.70 & 64.44 & $77.17^{b}$ \\
\hline $\begin{array}{l}\text { Pyriproxyfen } \\
10 \% \text { EW }\end{array}$ & $\begin{array}{c}75 \mathrm{ml} / 100 \text { liter } \\
\text { water }\end{array}$ & - & 59.53 & 63.30 & 65.20 & 50.28 & $59.58^{\mathrm{c}}$ \\
\hline
\end{tabular}

Means in columns followed by the same latter are not significantly different $(\mathrm{P} \leq 5 \%)$ according to Duncan's multiple range test (Duncan,1955)

Table(3): Reduction percentages in adults of Bemisiatabaciafter treatments with different insecticides on the tomato crop during season 2019

\begin{tabular}{|c|l|l|l|l|l|l|l|}
\hline \multirow{2}{*}{$\begin{array}{c}\text { Tested } \\
\text { insecticides }\end{array}$} & \multirow{2}{*}{$\begin{array}{c}\text { Recommended } \\
\text { rate }\end{array}$} & \multicolumn{5}{|c|}{ Reduction \% } & \multirow{2}{*}{$\begin{array}{c}\text { Mean } \\
\text { \% }\end{array}$} \\
\cline { 3 - 8 } & & 1day & 3days & 5days & 7days & 10days & \\
\hline $\begin{array}{c}\text { Acetamiprid } \\
\text { 20\%SP }\end{array}$ & $\begin{array}{l}25 \quad \text { gm/100 } \\
\text { liter water }\end{array}$ & 93.12 & 95.15 & 91.10 & 84.92 & 76.74 & $\mathbf{8 8 . 2 0}^{\mathbf{a}}$ \\
\hline $\begin{array}{c}\text { Chlorpyrifos- } \\
\text { methyl } \\
\text { 22.5\%EC }\end{array}$ & 1 liter/feddan & 89.45 & 87.44 & 83.97 & 78.04 & 69.66 & $\mathbf{8 1 . 8 2}^{\mathbf{b}}$ \\
\hline $\begin{array}{c}\text { Pyriproxyfen } \\
\mathbf{1 0 \% E W}\end{array}$ & $\begin{array}{l}75 \mathrm{ml} / 100 \text { liter } \\
\text { water }\end{array}$ & - & 61.47 & 65.48 & 67.35 & 60.18 & $\mathbf{6 3 . 6 2}^{\mathbf{c}}$ \\
\hline
\end{tabular}

A,b,c Means in columns followed by the same latter are not significantly different $\mathrm{P} \leq 5 \%$ according to Duncan's multiple range test (Duncan, 1955).

Data in Table (3) revealed significant differences between the tested compounds against whitefly, during 2019. Acetamiprid achieved the highest mean of reduction percent $(88.20 \%)$ while the mean of reduction percent of chlorpyrifos-methyl was $(81.82 \%)$ and $(63.62 \%)$ for pyriproxyfen. The levels of reduction exhibited by acetamiprid, pyriproxyfen and chlorpyrifos-methyl were increased more than that obtained throughout the season of 2018. These results were confirmed by Naranjo and Akey (2005) who carried out two field trials to test the potential of acetamipridin combating of Bemisiatabaci (Gennadius) in cotton compared with (IGRs) pyriproxyfen and buprofezin. 
Results showed that after treatment with acetamiprid, the population of B.tabaci became lower than that with pyriproxyfen, as acetamiprid is a fateful compound in the control of B.tabaci.

Conclusively, it was proved through this study that the neonicotined, acetamiprid was the most potent toxicant against $B$. tabaci, so we used acetamiprid in B. tabaci management.

\section{REFERENCES:}

Ahmad,M.; M.I.Arif, and M.Naveed (2010).Dynamics of resistance to organophosphate and carbamate insecticides in the cotton whitefly Bemisia tabaci (Hemiptera: Aleyrodidae) from Pakistan. J. Pest Sci., 83: 409-420.

Azab.M.M; F.A. El- Lakwah; Horeya.Abd- El Wahab; M. M. Khattab and Maha. S. M. El- Ghanam(2011). Impact of certain insecticides on enzymes activity of whitefly Bemisia tabaci (Genn.) and Aphis gossypii (Glover) on cucumber plants. Annals Of Agric. Sci. Moshtohor., 49 (2): 191-199.

Berlinger, M.J.(1986). Host plant resistance to Bemisiatabaci. Agric. Ecosystems Environ., 17: 69-82.

EFSA (2013).Scientific opinion on the risks to plant health posed by Bemisia tabaci species complex and viruses it transmits for the EU territory. EFSA Journal., 11(14): 3162.

Finney, D.J. (1971): Probit Analysis. A statistical treatment of the sigmoid response curve. $7^{\text {th }}$ Ed., Cambridge Univ. Press, England.

Ghanim, M. and H.Czosnek (2000). Tomato yellow leaf curl geminivirus (TYLCV-Is) is transmitted among whiteflies (Bemisiatabaci) in a sex-related manner. J. Virol., 74: 4738-4745.

Ghosal, A. and M.L.Chatterjee (2012). Bioefficacy of imidaclopride 17.8 SL against whitefly, Bemisia tabaci (Gennadius) in brinjal.Thejounal of Plant Protection Science.,5(1):37-41.

Hinderson, C.F. and E.W. Telton (1955). Test with acaricides against brown white mite. J. Econ., Entomol., 48:157-161.

Hunter,W.B. and J.E.Polston (2001).Development of a continuous whitefly cell line [Homoptera: Aleyrodidae:Bemisia tabaci (Gennadius)] for the study of Begomovirus. J. Invert. Pathol.,77: 3336. 
Horowitz, A.R.; Z. Mendelson; P.G. Weintraub, and I.Isshaya (1998).Comparative toxicity of foliar and systemic applications of acetamiprid and imidacloprid against the cotton whitefly, Bemisia tabaci (Homoptera: Aleyrodidae). Bull. Entomol. Res., 88: 437-442.

Ishaaya, I. and E.Swirski (1976). Trehalase, invertase and amylase activities in the black scale, Saissetiaoleae, and their relation to host adaptability. J. Insect Physiol.,16:1025-1029.

Lotrakul, P.; R. A. Valverde; C. A. Clark; J. Sim and D. L. Torre (1998). Detection of Gemini virus infecting sweet potato in the United States. Plant Dis., 82: 1253-1257.

Naranjo, E.S. and D.H.Akey (2005).Conservation of natural enemies in cotton: comparative selectivity of acetamiprid in the management of Bemisia tabaci. Pest Management Science.,61: 555-566.

Sayed Abdul Rahman, S. A. R; A. Sivapragasam; W. H. Loke and M. N. Mohd-Roff (2000). Whiteflies infesting vegetables in Malaysia. MARDI Research Station, Cameron high lands. Strategic, Environment and natural Resources Center, MARDI Serdang, CABISEARC,UPM Serdang, and MARDI Research station, Jalan Kebun.,pp.38-43.

$$
\begin{aligned}
& \text { الإنزيمات المحللة للكريوهيدرات وعلاقتها بمعاملات المبيدات الحشرية } \\
& \text { المختلفة في الأبابة البيضاء } \\
& \text { أميرة محمود محمد، عبد الحميد حسين مهنا1، حمزه محمد الشرقاوي 1، حسن }
\end{aligned}
$$

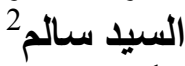

$$
\begin{aligned}
& 1 \text { قسم الانتاج النباتي_ كليه التكنولوجيا و التنميه ـ جامعه الزقازيق ـ الزقازيق - }
\end{aligned}
$$

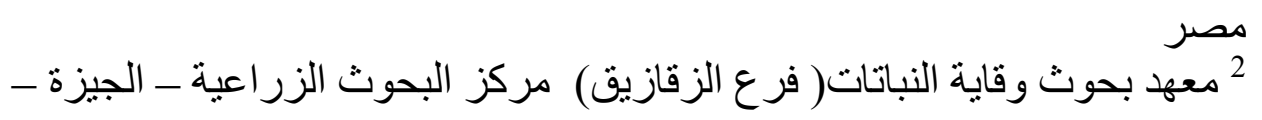

$$
\begin{aligned}
& \text { مصر }
\end{aligned}
$$

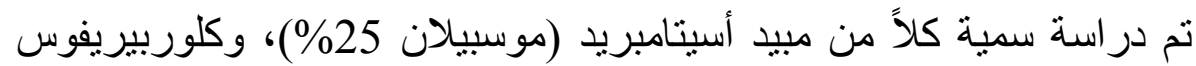

$$
\begin{aligned}
& \text { ميثيل( ريلدان 22.5\%)، وبيربروكسيفين (10\%) علي السلالتين المعدلية والحقلية }
\end{aligned}
$$

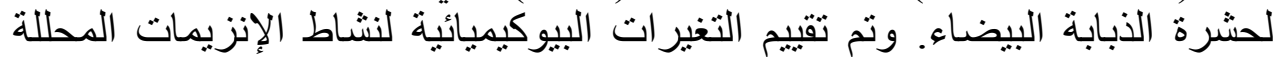

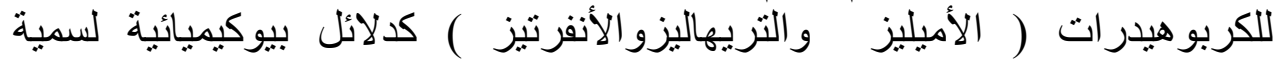


الأسيتامبريد والكلوربيريفوس ميثيل والبيرييروكسيفين في السلالتين المعملية و الحقلية.

وأوضحت النتائج أن المعاملة بهذه المبيدات أدت إلي إنخفاض نشاط كلاً من النان

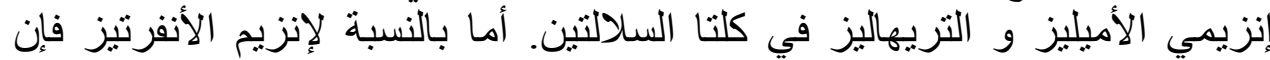

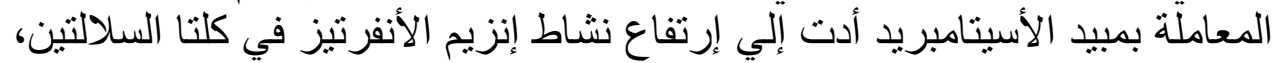

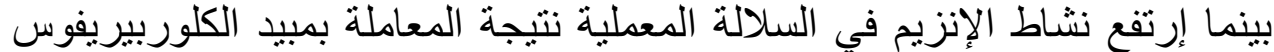

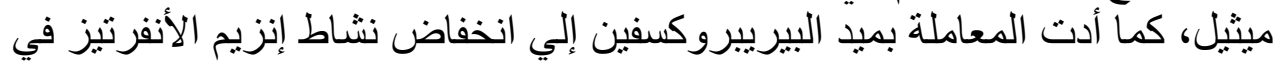
كلتا السلالتين.كما أجريت در اسة حقلية لتقييم كفاءة هذه المبيدات علي الذيفي الذبابة البيضاء

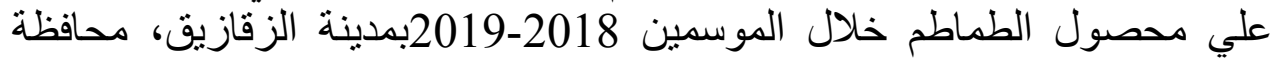
الثرقية.وأوضحت النتائج أن مبيد اسيتامبريد هو أكثر المبيدات فاعلية ضد هذه هذه الأفة في الموسمين حيث حقق 86.81 و88.20\% من نسبة الخفض في تعداد الذبابة

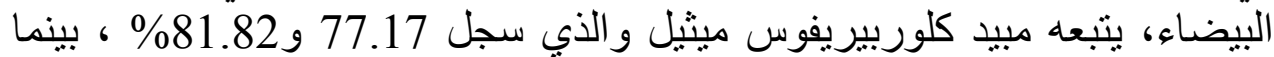

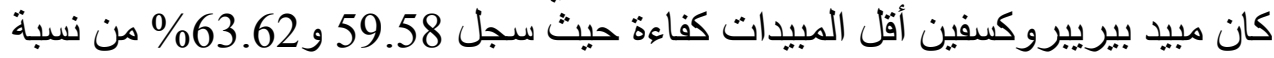
الخفض في تعداد الآفة في الموسمين التوصية: قد ثبت من خلال هذه الدراسة ان مبيد اسيتامبريد هو اكثر المبيدات فاعلية ضد حشرة الذبابة البيضاء، لذللك ننصح باستخدامه فى مكافحة هذه الافة الته. 